\title{
PERAN KEPEMIMPINAN KEPALA MADRASAH DALAM MENGEMBANGKAN BUDAYA MADRASAH
}

\author{
Mulyadi
}

\author{
Staf Pengajar pada PGMI Fakultas Tarbiyah UIN Malang
}

\begin{abstract}
The leadership of madrasa plays an important role in improving strong madrasa culture since such culture is influenced by how far the leadership of madrasa guides this school activities, both tangible and intangible guiding to establish strong madrasa culture. The strong madrasa culture can be established by four dimensions, namely commitment, capability, cohesion, and consistency. The role of such leadership in improving strong madrasa culture is a series of precess from the entirely madrasa organizational systems.

The leadership role of madrasa in developing madrasa culture are to articulate the madrasa vision an mission, the values an belief within madrasa organizational, to create the madrasa symbol which is able to strengthen the unique of madrasa school organizational, to establish such reward system based on the norm and value of madrasa, to build the social and emotional relationship among teacher, student, and society based on the commitment and its mission and to design the structural of madrasa
\end{abstract}

Keywords: leadership, developing, madrasa culture

\section{A. Pendahuluan}

Kepemimpinan adalah proses mempengaruhi dalam menentukan tujuan organisasi, memotivasi perilaku pengikut untuk mencapai tujuan, mempengaruhi untuk memperbaiki kelompok dan budayanya. Selain itu juga mempengaruhi interpretasi mengenai peristiwa-peristiwa para pengikutnya, pengorganisasian dan aktivitas-aktivitas untuk mencapai sasaran, memelihara hubungan kerjasama dan kerja kelompok, perolehan dukungan dan kerjasama dari orang-orang di luar kelompok atau organisasi.

Secara khusus Yukl menyatakan bahwa: memahami kepemimpinan sebagai sebuah proses mempengaruhi dalam suatu kelompok untuk mencapai tujuan orang secara bersama. Hal ini dapat dipahami dari penjelasan sebagai berikut: Kepemimpinan didefinisikan secara luas sebagai proses-proses yang mempengaruhi interpretasi mengenai peristiwa-peristiwa para pengikut, pilihan dari sasaran-sasaran bagi kelompok atau orang, pengorganisasian dari aktivitas-aktivitas tersebut untuk mencari sasaran, pemeliharaan hubungan, kerjasama dan teamwork, serta perolehan dukungan dan kerja sama dari orang-orang yang berada di luar kelompok atau orang (Yukl, G., 1999: 1). 
Hal tersebut memberi penjelasan bahwa kepemimpinan merupakan proses-proses mempengaruhi, memotivasi, pengorganisasian aktivitas tersebut untuk mencapai sasaran. Motivasi dari para pengikut untuk mencapai sasaran, pemeliharaan hubungan kerjasama dengan teamwork untuk mencapai sasaran dan tujuan organisasi. Hal ini dapat dipahami bahwa kepemimpinan mencakup hubungan pemimpin dengan anggota organisasi untuk mencapai tujuan yang sudah ditetapkan.

Kajian-kajian kepemimpinan sekitar tahun 60-an telah berkembang. Di kalangan para ilmuwan perilaku yang secara khusus mendalami dan cenderung memahami kepemimpinan dalam konteks perilaku pemimpin yang otoriter. Kecenderungan, untuk memahami kepemimpinan secara organik kepemimpinan seperti mekanisme dalam mempengaruhi anggota organisasi disyaratkan dalam sistem birokrasi ketat dan kaku, sehingga penekanan kepemimpinan selalu berada pada sikap pemimpin yang otoriter dan mengabaikan sisi sosial budaya dari organisasi, mengabaikan budaya yang tidak tampak. Dari sini lahir pemahaman bahwa seorang pemimpin yang kuat diperlukan dalam birokrasi yang ketat dan kaku.

Dewasa ini pengertian kepemimpinan dalam sejumlah kajian memiliki nuansa sosial budaya lebih kuat. Hal ini didasari pencitraan sosiologis terhadap organisasi sehingga dilihat dari sistem sosial yang memiliki dimensi sosial budaya. Kepemimpinan tidak lagi dipahami secara organik tetapi merupakan dimensi organisasi yang mempunyai konstribusi untuk membangun budaya organisasi yang sehat. Menurut Willer Lane et al seperti dikutip Hanson, kepemimpinan memiliki dimensi sosial budaya seperti dijelaskan berikut ini:

For although leaders deal directly with individual it is organizations that is, group tradition, establish relationship, and vested interest group which are their main concern. Clearly the problems, dilemmas, and inconsistencies of organizations and of the society are the problems of the leaders. They constitute the leadership setting (Hanson E.M., 1991: 184).

Dari kutipan tersebut dapat dipahami bahwa kepemimpinan terkait langsung dengan kebiasaan kelompok, melakukan hubungan. Perhatian pada kelompok berkepentingan dalam suatu organisasi. Pemimpin hendaknya berupaya untuk membangun tradisi kelompok melalui hubungan kerja dengan anggota organisasi dengan berupaya memecahkan masalah-masalah masyarakat.

Menurut Owens, menegaskan kepemimpinan merupakan dimensi hubungan sosial dalam organisasi dalam rangka memberikan pengaruh antara individu atau kelompok melalui interaksi sosial, mengidentifikasi kepemimpinan sebagai berikut:

Leaderships is function of group, not individual. We speak of course of individual as being leaders but leadership occurs of two of more people 
interacting. An interacting process one person is able to induce others to think and behave in certain desired ways that beings up the second key point which in influence leadership involves intentionally exercising influence organization behavior of other people (Owens R.G., 1991: 132).

Secara khusus kepemimpinan di madrasah mempunyai penekanan pada pentingnya posisi kepemimpinan untuk meningkatkan kualitas dan efektivitas madrasah. Berbagai kutipan tersebut menekankan adanya dimensi sosial budaya dalam kepemimpinan. Di mana kepemimpinan berlangsung interaksi individu atau kelompok (siswa, guru, kepala madrasah, orangtua, masyarakat dan karyawan). Muara besar dari interaksi tersebut adalah terbentuknya budaya organisasi madrasah yang kuat sehingga pendidikan dapat berlangsung dengan efektif dan efisien.

Dalam Islam kepemimpinan identik dengan istilah khalifah yang berarti wakil. Pemakaian kata khalifah setelah Rasulullah SAW wafat menyentuh juga maksud yang terkandung dalam perkataan amir (jamaknya umara) atau penguasa. Kedua istilah itu dalam bahasa Indonesia disebut pemimpin formal. Namun jika merujuk kepada firman Allah SWT dalam surat al Baqarah (2) ayat 30 yang berbunyi:

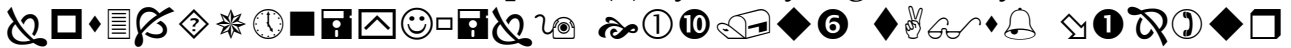

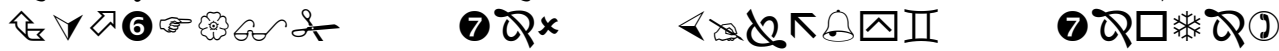

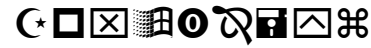

Artinya: "Ingatlah ketika Tuhanmu berfirman kepada para malaikat, sesungguhnya aku hendak menjadikan seorang khalifah di muka bumi" [Q.S. al Baqarah (2): 30].

Maka kedudukan non formal dari seorang khalifah juga tidak dapat dipisahkan lagi. Perkataan khalifah dalam ayat tersebut tidak hanya ditujukan kepada khalifah sesudah nabi tapi adalah penciptaan Nabi Adam AS yang disebut sebagai manusia dengan tugas untuk memakmurkan bumi yang meliputi tugas menyeru orang lain berbuat amar ma'ruf dan mencegah dari perbuatan mungkar.

Selain kata khalifah disebutkan juga kata ulil amri yang satu akar dengan kata amir sebagaimana disebutkan di atas. Kata ulil amri berarti pemimpin tertinggi dalam masyarakat Islam sebagaimana firman Allah SWT dalam surat al Nisa' (4) ayat 59:

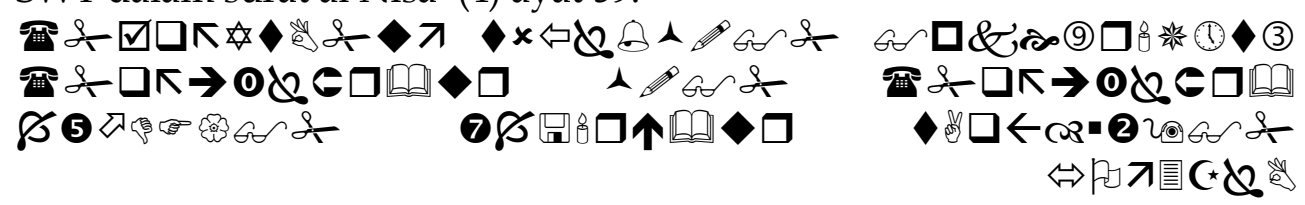

Artinya: "Hai orang-orang yang beriman taatilah Allah dan taatilah Rasulnya dan ulul amri di antara kamu" [Q.S. al Nisa' (4): 59]. 
Sedangkan dalam Surat al Nisa' (4) ayat 83 kata ulil amri mungkin berarti pemimpin tertinggi atau hanya pemimpin Islam yang mengepalai suatu jawatan:

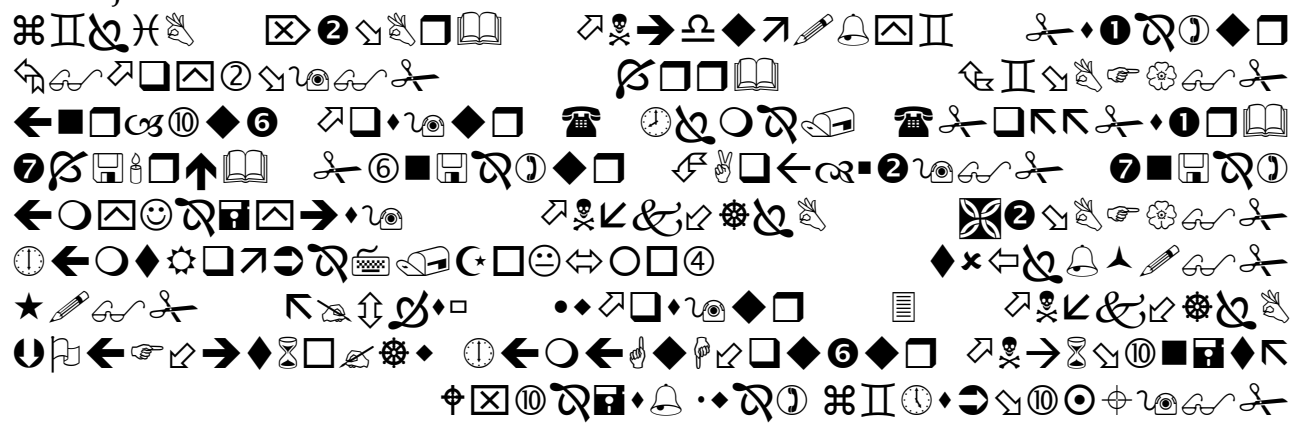

Artinya: "Dan apabila datang kepada mereka suatu berita tentang keamanan ataupun ketakutan, mereka lalu menyiarkannya. Dan kalau mereka menyerahkannya kepada Rasul dan ulil amri (tokoh-tokoh sahabat dan para cendekiawan) di antara mereka, tentulah orang-orang yang ingin mengetahui kebenarannya (akan dapat) mengetahuinya dari mereka (Rasul dan ulil amri). Kalau tidaklah karena karunia dan rahmat Allah kepada kamu tentulah kamu mengikuti syaitan, kecuali sebagian kecil saja (di antaramu)" [Q.S. al Nisa' (4): 83].

Hal tersebut menunjukkan bahwa ulil amri yang dipaparkan dalam kedua ayat tersebut bukan penguasa atau pemerintah kafir yang menjajah masyarakat Islam dan juga bukan pemimpin musyrik atau munafik.

Dalam Al Qur'an juga disebutkan istilah auliya yang berarti pemimpin yang sifatnya resmi dan tidak resmi. Sesuai dengan firman Allah SWT dalam surat al Maidah (5) ayat 55:

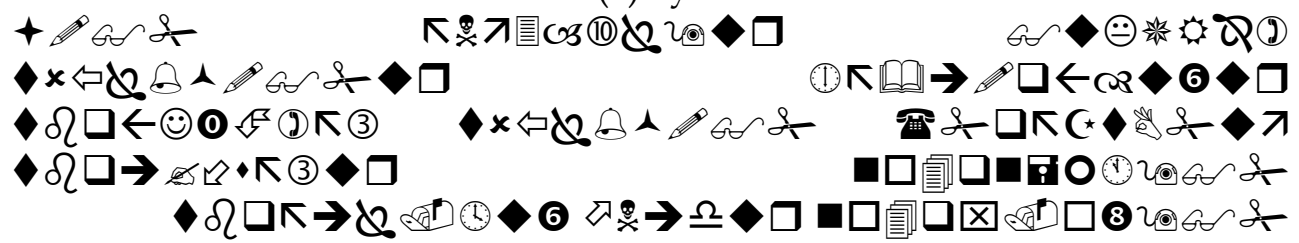

Artinya: "Sesungguhnya penolong kamu hanyalah Allah, Rasulnya dan orang-orang yang beriman yang mendirikan shalat dan menunaikan zakat seraya mereka tunduk kepada Allah" [Q.S. al Maidah (5): 55].

Dalam hadits Rasulullah SAW istilah pemimpin dijumpai dalam kata ra'in atau amir seperti yang disebutkan dalam hadits yang diriwayatkan Imam Bukhari:

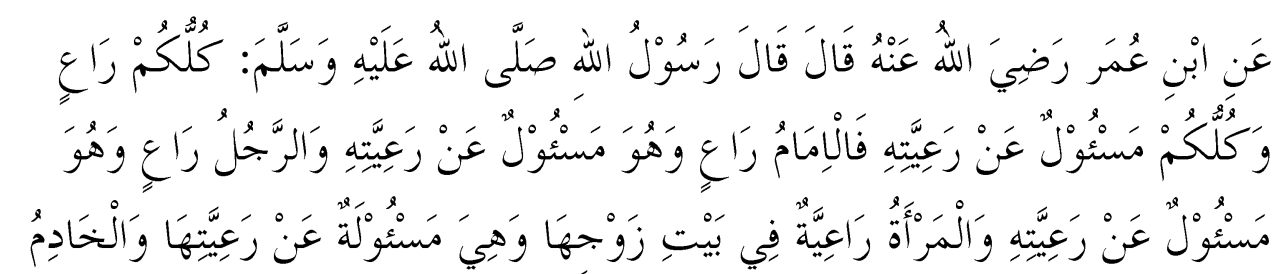




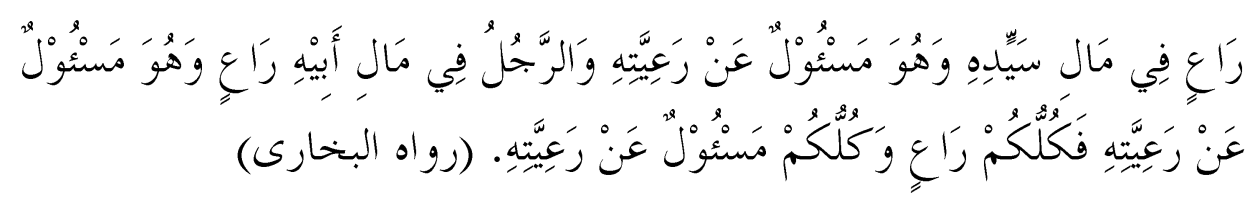

Artinya: "Dari ibn 'Umar r.a. dia berkata: bahwa Rasulullah SAW. telah bersabda: Setiap orang di antaramu adalah pemimpin dan setiap kamu akan bertanggungjawab atas kepemimpinannya, seorang imam adalah pemimpin dan dia akan bertanggungjawab atas kepemimpinannya, orang laki-laki (suami) adalah pemimpin dan dia akan bertanggungjawab atas kepemimpinannya, orang perempuan (istri) adalah pemimpin di dalam rumah suaminya dan dia akan dimintai pertanggungjawaban atas kepemimpinannya, dan pembantu adalah pemimpin (pemelihara) harta benda tuannya dan dia akan dimintai pertanggungjawaban atas kepemimpinannya (pemeliharaannya), dan seorang anak adalah pemimpin (pemelihara) harta benda ayahnya dan dia akan dimintai pertanggungjawaban atas kepemimpinannya (pemeliharaannya), maka (sekali lagi), setiap orang di antaramu adalah pemimpin dan setiap kamu akan bertanggungjawab atas kepemimpinannya". (H.R. Bukhari). [AlBukhari, Shahih Bukhari, Hadits no. 844].

Berdasarkan ayat Al Qur'an dan hadits Rasulullah SAW tersebut dapat disimpulkan bahwa kepemimpinan Islam adalah kegiatan menuntun, membimbing, memandu dan menunjukkan jalan yang diridlai Allah SWT.

Berdasar uraian di atas dapat diidentifikasi beberapa komponen dalam kepemimpinan yaitu: (1) Adanya pemimpin dan orang lain yang dipimpin, (2) Adanya upaya atau proses mempengaruhi dari pemimpin kepada orang lain melalui berbagai kekuatan, (3) Adanya tujuan akhir yang ingin dicapai bersama dengan adanya kepemimpinan itu (4) Kepemimpinan bisa timbul dalam suatu organisasi atau tanpa adanya organisasi tertentu, (5) Pemimpin dapat diangkat secara formal atau dipilih oleh pengikutnya, (6) Kepemimpinan berada dalam situasi tertentu baik situasi pengikut maupun lingkungan eksternal, (7) Kepemimpinan Islam merupakan kegiatan menuntun, membimbing, memandu dan menunjukkan jalan yang diridlai Allah SWT.

\section{B. Pengertian dan Jenis-jenis Budaya Madrasah}

Budaya madrasah sebenarnya merupakan persoalan lama tetapi belum banyak dikaji secara mendalam di Indonesia. Budaya madrasah pada dasarnya sama dengan budaya organisasi. Secara umum sebenarnya budaya madrasah atau budaya organisasi tidak berbeda dengan budaya masyarakat yang sudah dikenal selama ini. Perbedaan pokok terletak pada lingkupnya sehingga kekhususan dari budaya madrasah berakar dari lingkupnya, dalam hal ini lebih sempit dan lebih spesifik. Budaya 
organisasi telah didefinisikan oleh banyak ahli baik dari kalangan manajemen, sosial, antropologi, maupun organisasi, di antaranya:

1. Martin (1985), budaya organisasi adalah serangkaian sikap, nilai, keyakinan yang umumnya diciptakan untuk mengarahkan perilaku organisasi.

2. Schein (1989), budaya organisasi adalah seperangkat asumsi dasar yang diciptakan, ditemukan, atau dikembangkan dan dianut bersama sebagai pembelajaran untuk mengetesi masalah masalah adaptasi dengan lingkungan eksternal dan integrasi internal.

3. Kilmann (1988), budaya organisasi adalah filosofi, ideologi, nilainilai, keyakinan, asumsi-asumsi dan norma-norma yang dianut bersama. Budaya adalah kekuatan yang tidak nampak di balik sesuatu yang nyata dan dapat diamati di berbagai organisasi, sebagai energi sosial yang mengarahkan manusia dalam bertindak.

4. Robbin (1998), budaya organisasi adalah suatu persepsi bersama yang dianut oleh anggota anggota organisasi itu; suatu sistem dari makna bersama.

Berangkat dari berbagai pengertian tentang budaya di atas, dapat dipahami bahwa budaya madrasah adalah sistem makna untuk membina mental agar pemikiran dan tindakan warga madrasah didasarkan pada pertimbangan moral dan dapat dipertanggungjawabkan. Budaya madrasah didefinisikan sebagai seperangkat asumsi yang dibangun dan dianut bersama oleh organisasi madrasah sebagai moral dalam beradaptasi dengan lingkungan eksternal dan proses integrasi internal. Seperangkat asumsi dimaksud adalah filosofi, nilai nilai, norma-norma, keyakinan, ide, mitos, dan karya yang terintegrasi untuk mengarahkan perilaku organisasional. Sedangkan seperangkat asumsi tersebut merupakan isi budaya madrasah yang berkaitan dengan apa yang dipikirkan, dirasakan, dan dilakukan oleh semua warga madrasah. Isi budaya adalah moral yaitu watak organisasi yang mengutamakan nilai-nilai kebaikan yang harus diterima dan disepakati untuk menjadi roh kehidupan organisasi.

Budaya organisasi dalam praktek kegiatan sehari-hari dapat dilihat dalam empat tingkatan seperti tampak pada gambar 1., yaitu:

1. Artifak, yaitu hal-hal yang terlihat, terdengar dan terasakan ketika oleh seseorang dari luar organisasi ketika memasuki organisasi tersebut yang sebelumnya tidak dikenalnya. Secara fisik artifak dapat dilihat dari produk, jasa dan tingkah laku anggota organisasi yang bersangkutan. Di dalam organisasi itu sendiri, artifak antara lain tampak dalam struktur dan proses-proses organisasi.

2. Norma dalam organisasi tampak dalam aturan-aturan tertulis maupun kesepakatan tidak tertulis. Di dalamnya mengandung arahan positif dan sanksi terhadap pelanggaran dalam organisasi. 
3. Nilai-nilai yang ada dalam organisasi yang menjadi daya tarik sehingga orang di luar organisasi tersebut tertarik untuk masuk ke dalamnya. Secara umum nilai-nilai inilah yang menjadi akar dari budaya organisasi, utamanya bila nilai-nilai yang dimaksudkan didukung oleh anggota kelompok. Adapun bentuk dari nilai-nilai yang dimaksudkan di antaranya tampak dari pengorbanan anggota dalam melakukan pekerjaan organisasi. Dari sisi organisasi, nilainilai tersebut akan tampak pada tujuan dan strategi organisasi.

4. Asumsi-asumsi dari keyakinan yang dianggap sudah ada oleh anggota organisasi. Asumsi-asumsi ini seringkali tidak tertulis atau terucapkan. Asumsi dan keyakinan yang kuat akan muncul antara lain dalam praktek manajemen yang tertata baik. Sebaliknya, manajemen sebuah organisasi yang kurang tertata mencerminkan asumsi atau keyakinan yang tidak kuat, sehingga budaya organisasinya juga kurang jelas. Bagi anggota, keyakinan, asumsi, dan berbagai persepsi organisasi tercermin dalam perasaan dan pikiran mereka terkait dengan organisasinya.

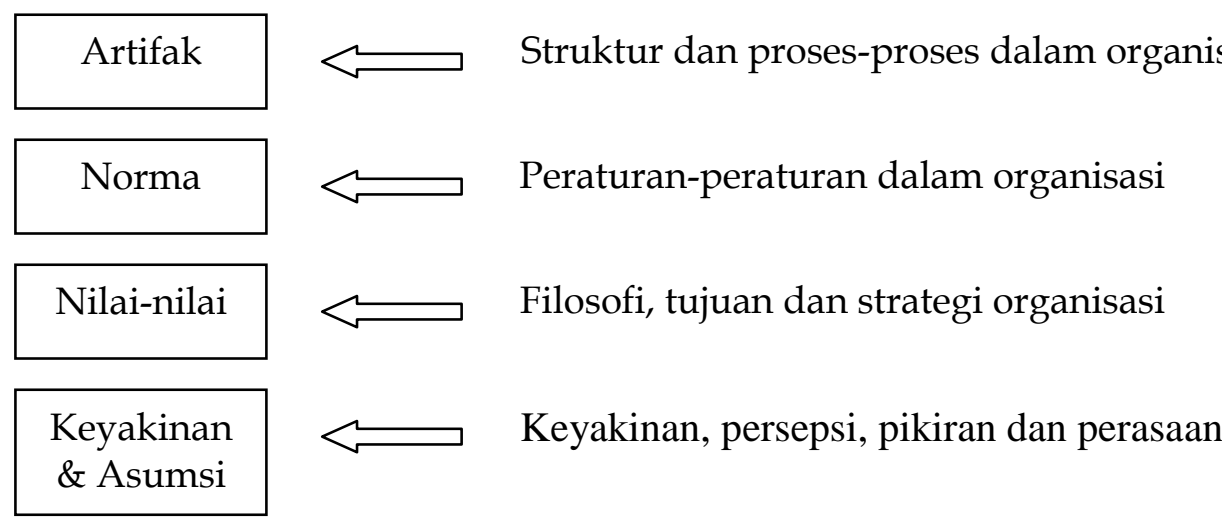

\section{Gambar 1. Tingkatan Budaya Organisasi}

(Sumber: Schein, H.E., 1992: 17)

Budaya madrasah akan berpengaruh besar terhadap kehidupan di madrasah, meskipun tidak selamanya berdampak positif. Budaya yang memiliki pengaruh besar terhadap kehidupan madrasah adalah budaya yang kuat. Hal ini dapat terjadi ketika seluruh jajaran di madrasah tersebut sepakat tentang nilai-nilai tertentu yang menjadi dasar dari tindakan anggota dan madrasah sebagai organisasi. Pada sisi lain, tidak tertutup kemungkinan bahwa budaya madrasah mungkin saja belum benar-benar terbentuk atau sudah terbentuk tetap belum kuat. Keadaan seperti ini terjadi ketika di madrasah itu belum ada kesepakatan tentang nilai-nilai yang dijadikan dasar tindakan atau nilai-nilai sudah disepakati tetapi tidak dapat dijalankan secara konsisten. 
Agar hal tersebut dapat diwujudkan, dibutuhkan setidaknya dua kondisi, yaitu komitmen pada nilai-nilai yang dianut dan share nilai pada anggota organisasi atau madrasah tersebut (lihat Skema 2). Komitmen pada nilai harus tercermin pada organisasi secara keseluruhan sehingga muncul dalam visi, isi, tujuan, dan perilaku organisasi. Sementara itu, anggota bisa sejalan namun bisa juga kurang sejalan dengan nilai-nilai yang dianut organisasi. Keselarasan nilai-nilai organisasi dengan anggota sebagai individu akan memperkuat budaya madrasah sebagai organisasi.

Budaya yang kuat akan terwujudkan dalam berbagai jenis atau tipe. Akhir-akhir ini ada keyakinan bahwa budaya yang kuat dan sesuai dengan tuntutan perkembangan dunia pada umumnya adalah budaya adaptif. Madrasah sebagai sebuah organisasi akan mengalami berbagai persoalan bila tidak dapat menyesuaikan dengan perkembangan di luar madrasah dan perkembangan dunia pada umumnya. Budaya yang demikian antara lain ditandai oleh adanya perhatian yang tinggi terhadap stakeholders dan menghargai orang atau proses yang dapat membuat perubahan. Untuk dapat melakukan hal itu maka madrasah harus dapat melayani semua pihak di dalam madrasah dan percaya kepada pihak lain di luar madrasah. Dalam perilaku sehari-hari pimpinan madrasah akan memberi perhatian kepada berbagai pihak, berinisiatif melakukan perubahan, dan berani mengambil resiko untuk melakukan perubahan.

\begin{tabular}{|r|c|c|}
\cline { 2 - 3 } $\begin{array}{r}\text { Kuat } \\
\text { Komitmen pada } \\
\text { nilai }\end{array}$ & $\begin{array}{r}\text { Budaya sedang } \\
\text { (bergerak) }\end{array}$ & Budaya kuat \\
\cline { 2 - 3 } Lemah & Budaya lemah & $\begin{array}{c}\text { Budaya sedang } \\
\text { (stabil) }\end{array}$ \\
\cline { 2 - 3 } & Sedikit & Banyak
\end{tabular}

Jumlah anggota berbagi nilai

\section{Gambar 2. Implikasi Lemah Kuatnya Budaya Madrasah}

(Sumber: Siagian, 1995: 236)

Persoalannya organisasi pada umumnya dan madrasah khususnya disinyalir banyak yang belum memiliki budaya yang kuat terutama yang tipenya adaptif. Bila kenyataannya demikian, maka perlu dilihat secara lebih rinci budaya yang berkembang di madrasah. Secara teoritis, untuk melihat budaya madrasah dapat digunakan dua indikator pokok, yaitu fleksibilitas dan fokus dari aktivitas madrasah. Fleksibilitas dapat dilihat dari dua titik ekstrim, yaitu fleksibel dan statis. Fokus dapat dilihat dari dua sisi, yaitu fokus internal dan fokus eksternal. Dengan menggunakan dua indikator yang masing-masing memiliki dua kutub maka dapat dibuang empat tipe budaya madrasah. Pertama, bila madrasah tersebut fleksibel dan fokusnya adalah eksternal maka budaya yang berkembang 
adalah budaya adaptif. Kedua, bila madrasah tersebut fleksibel tetapi fokusnya internal maka budayanya adalah kekeluargaan. Ketiga, bila organisasinya cenderung stabil (tidak fleksibel) dan fokusnya eksternal maka budaya yang berkembang adalah budaya prestasi. Terakhir, bila organisasi cenderung stabil dan fokusnya internal maka budayanya adalah birokrati. Untuk lebih jelasnya, tipe budaya yang dimaksud digambarkan sebagai berikut:

\section{Fleksibel}

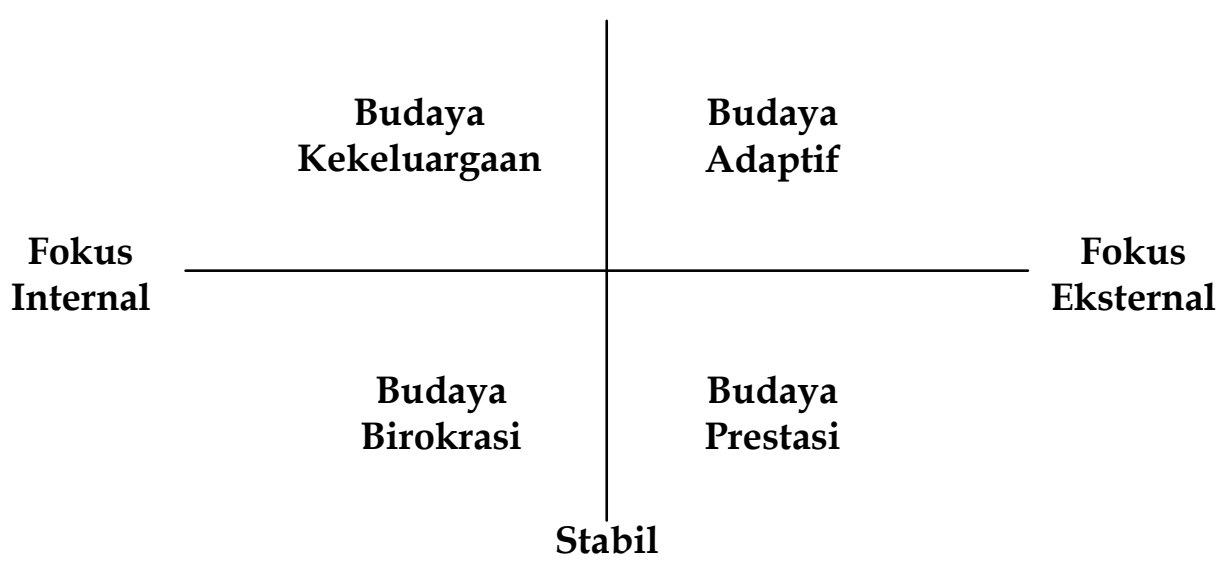

\section{Gambar 3. Jenis-jenis Budaya Madrasah}

(Sumber: Daff: 1999)

Secara lebih rinci, masing-masing budaya memiliki nilai-nilai yang dapat dijadikan ciri-ciri untuk mendeteksi keadaan di lapangan. Budaya adaptif memiliki ciri-ciri sebagai berikut:

1. Kreatif. Madrasah yang memiliki budaya adaptif akan memiliki kreatifitas yang tinggi dalam membuat rancangan program atau kegiatan, merespons persoalan yang muncul dan dalam memecahkan masalah yang muncul. Kreatifitas ini sangat penting untuk masamasa yang penuh dengan perubahan seperti sekarang ini.

2. Berani melakukan eksperimentasi. Sejalan dengan kreatifitas yang tinggi, madrasah dengan budaya adaptif juga berani melakukan eksperimen atau mencoba hal-hal baru. Meskipun demikian, eksperimentasi tidak berarti melakukan coba-coba tanpa terkendali. Sebagai organisasi, eksperimentasi di dalamnya dapat dilakukan secara terencana dan sistematis.

3. Berani mengambil resiko. Konsekuensi dari kreatifitas dan eksperimentasi adalah resiko. Bagi sebagian orang dan organisasi yang tidak adaptif ada kecenderungan takut mengambil resiko yang berasosiasi dengan kerugian. Sebaliknya, di balik resiko selalu ada keuntungan yang akan diperoleh. Di sini yang diperlukan adalah 
memperhitungkan resiko dan keuntungan sekaligus sehingga hasilnya lebih menguntungkan.

4. Mandiri. Kemandirian organisasi mencerminkan adaptabilitasnya karena hal ini menggambarkan otoritas yang dimilikinya. Tanpa kemandirian, sebuah organisasi tidak akan mampu beradaptasi dengan baik, yang terjadi justru sebaliknya yaitu mengikuti dan terikat pada pihak lain.

5. Responsif. Persoalan organisasi tidak sebatas pada persoalanpersoalan yang ada di dalamnya. Saat ini justru terjadi sebaliknya, persoalan di luar organisasi berkembang dengan sangat cepat. Oleh karena itu, untuk bisa dikatakan adaptif sebuah organisasi harus responsif terhadap persoalan-persoalan di luar dirinya. berikut:

Sementara itu, ciri-ciri budaya kekeluargaan adalah sebagai

1. Mengedepankan kerjasama. Ciri-ciri kekeluargaan adalah kebersamaan yang dalam organisasi termanifestasikan sebagai kerjasama. Dari sisi ini, budaya kekeluargaan tidak mengindikasikan kelemahan.

2. Penuh pertimbangan. Ada kecenderungan di dalam budaya kekeluargaan bahwa pertimbangan yang dilakukan mengarah pada tindakan yang sangat hati-hati. Hal ini akan menjadi masalah bila mengarah pada kelambanan dan kekurangproduktifan.

3. Persetujuan bersama. Dalam budaya kekeluargaan keputusan bisa diambil bila semua pihak menyetujui. Sebagai unsur demokrasi hal ini sangat baik namun akan muncul persoalan bila proses ini menghambat responsifitas terhadap persoalan yang muncul dan kreatifitas anggotanya.

4. Kesetaraan. Sejalan dengan kerjasama dan keputusan bersama, posisi anggota di dalam organisasi dengan budaya kekeluargaan akan setara.

5. Keadilan. Konsep keadilan yang diterapkan dalam organisasi dengan budaya kekeluargaan adalah pemerataan.

Budaya prestasi memiliki ciri-ciri sebagai berikut:

1. Berorientasi pada persaingan atau kompetisi. Anggota organisasi dalam budaya ini diberi kesempatan untuk mengembangkan diri semaksimal mungkin sehingga dapat mengungguli lainnya. Keunggulan anggota-anggota ini akan dijadikan modal sebagai keunggulan organisasi yang nantinya siap untuk berkompetisi dengan organisasi lain. 
2. Mengumpulkan kesempurnaan. Sejalan dengan upaya untuk menjadi organisasi yang unggul, elemen-elemen dalam organisasi juga didorong untuk mencapai kesempurnaan kinerja. Dengan demikian, anggota maupun organisasi dapat tampil dengan kepercayaan diri yang tinggi.

3. Agresif. Budaya prestasi mengarah pada keunggulan dan kemenangan. Untuk mendukung hal itu, diperlukan agresivitas yang tinggi.

4. Aktif dan rajin. Di dalam organisasi maupun dalam relasi dengan organisasi lain, budaya prestasi mengutamakan keaktifan anggota dan organisasi secara keseluruhan. Orientasi ini diperlukan sebagai persiapan untuk menghasilkan sesuatu dan prestasi yang tinggi.

5. Mendorong munculnya inisiatif anggota. Kekuatan organisasi dengan budaya prestasi adalah kinerja yang tinggi. Salah satu modal pentingnya adalah inisiatif anggota. berikut:

Budaya birokrasi ditandai adanya dominasi ciri-ciri sebagai

1. Formalitas hubungan di dalam maupun dengan pihak luar madrasah. Sebuah organisasi yang birokratis memiliki struktur dan proses kerja yang jelas dan tidak dapat diubah segera. Hal ini dirancang untuk mengatur pola hubungan yang baku dan formal.

2. Mementingkan efisiensi. Pembakuan-pembakuan dan formalitas yang dilakukan dalam organisasi diarahkan untuk mencapai efisiensi.

3. Menekankan rasionalitas. Indikator ini merupakan dasar dari berbagai hal yang ada dalam organisasi, termasuk efisiensi, keteraturan, dan kepatuhan. Artinya, budaya birokrasi didasarkan pada rasionalitas yang kuat.

4. Teratur dan berjenjang. Sejalan dengan kaidah birokrasi, maka keteraturan dan hirarkhi sangat dipentingkan.

5. Menuntut adanya kepatuhan dari pihak-pihak di bawah pimpinan. Begitu peraturan digariskan dan hirarkhi disepakati, maka anggota organisasi tinggal mengikuti dan pemimpin melakukan kontrol terhadap bawahan dan anggota.

\section{Peran Kepemimpinan Kepala Madrasah dalam Mengembangkan Budaya Madrasah}

Kepemimpinan kepala madrasah pada budaya madrasah merupakan kajian yang relatif baru dalam organisasi. Kajian ini berdasarkan asumsi bahwa kepemimpinan madrasah akan lebih efektif 
apabila didukung kondisi budaya organisasi yang kuat. Lebih dari penafsiran biasanya, bahwa kepemimpinan ini, memberi orientasi pada terbentuknya budaya organisasi yang kuat (strong cultural) guna mendukung kesuksesan pencapaian tujuan madrasah.

Sebagaimana kepemimpinan mempunyai makna atau pengertian yang beragam, maka kepemimpinan pada budaya, dapat diartikan sebagai upaya-upaya pemimpin untuk mempengaruhi, merubah atau mempertahankan budaya organisasi yang kuat untuk mendukung terwujudnya pencapaian tujuan serta visi, nilai keyakinan dan perilaku pemimpin menjadi bagian penting untuk melihat keefektifan kepemimpinan kepala madrasah pada budaya madrasah. Itulah sebabnya bahwa pemimpin akan berupaya untuk membangun budaya organisasi madrasah dengan didasari nilai, keyakinan dan perilaku yang dimilikinya.

Pemahaman yang luas tentang kepemimpinan pada budaya madrasah dapat dilihat pada penjelasan Owens tentang pengaruh kepala madrasah dalam membangun budaya madrasah yang kuat (the strong cultural school), ia menjelaskannya sebagai berikut:

Leadership who would strong organization cultures in school spend time articulating the purpose and the mission of the school; they socialize others to these values; they define and redefine in the uniqueness of the school; they develop system of symbol that reinforce the uniqueness and make sure that the symbols are highly visible; they reward those who accept and reflect the norms and value of the school. School in which the happens are characterized by the bonding that occurs between people, and between people and organization in which they have faith and toward which they have commitment. Under such leadership, student and teacher a like come to understand that they are part of and important and worthwhile of large mission. This, in it self, give meaning of their daily efforts and includes them as part of something special and important. Under the cultural leadership, therefore, student, and teacher find satisfaction in being parts of a special group at special moment of achievement (Owens R.G., 1991: 161).

Dari kutipan di atas dapat dipahami bahwa kepemimpinan kepala madrasah dalam mengembangkan budaya madrasah merupakan upayaupaya untuk mengartikulasikan tujuan dan misi madrasah, nilai-nilai madrasah, keunikan madrasah, sistem simbol madrasah, imbalan yang memadai, ikatan organisatoris berdasarkan saling percaya dan komitmen antar guru, siswa dan masyarakat. Kepala madrasah diharapkan dapat membangun budaya madrasah yang kuat untuk meningkatkan keefektifan madrasah untuk mencapai tujuan madrasah

Bahkan Dwyer dalam Sergiovanni, menjelaskan kepemimpinan madrasah pada budaya madrasah: 
Another fundamental characteristic of these principals was the routine nature of their actions. Instead of leaders of large scales or dramatic innovation, we found men and women who shared meticulous attention to detail. We observed an attention to physical and emotional elements of school environment, school community relations, the teaching staffs, schoolwides student achievement, and individual student progress... (Thomas J. Sergiovanni, et. al., 1991: 107).

Pada kutipan di atas dijelaskan bahwa kepemimpinan kepala madrasah dalam mengembangkan budaya menunjuk pada upaya-upaya kepala madrasah untuk melakukan inovasi, perhatian menyeluruh terhadap lingkungan madrasah, hubungan masyarakat, pendidikan guru, prestasi siswa, dan kemajuan siswa.

Lebih lanjut Sergiovanni menjelaskan tentang peran kepala madrasah dalam membentuk budaya madrasah yang bermuara pada visi dan kualitas pendidikan sebagai berikut:

All school have cultures, but successful schools seem to have strong and functional cultures aligned with a vision of quality schooling. Culture serve as a compass setting of steer people in a common direction; it provides a sets of norms defining what people in comment direction, and it is source of meaning and significance for teacher, student, administrator, and others as they work. Strong and functional cultures are domesticated in the sense that they emerge deliberately-they are nurtured and built by the school leadership and membership (Thomas J. Sergiovanni, et. al., 1991: 108).

Pada kutipan di atas, juga dapat dipahami kepemimpinan kepala madrasah mempunyai peran penting dalam membangun budaya di madrasah. Budaya madrasah akan memberikan seperangkat norma yang dibutuhkan anggota organisasi madrasah. Sehingga budaya dapat memberikan pemaknaan yang kuat terhadap apa yang dilakukan para guru, siswa dan karyawan di madrasah. Bangunan budaya madrasah yang kuat dilandasi dengan kemampuan kepala madrasah untuk memberikan pemaknaan terhadap visi tentang mutu madrasah.

Sedangkan Caldwell dan Spink memberikan penjelasan tentang kepemimpinan kepala madrasah yang terfokus pada upaya-upaya untuk menciptakan budaya unggul di madrasah. Seperti dijelaskan sebagai berikut:

School leader should be able to describe and analyze the culture of the school. School leader should be able to work with others in the school community to define elements of excellence which are relevant to their setting, and to identify and resolve inconsistencies between these and the various manifestations of culture in their school. The creation for changing of a school's culture. School leader should be able to see the larger picture discerns the mega trends-appreciated that elements of school's culture are 
in many respect determined by forces which are sharing society as a whole, whole our personal view of excellence outlined earlier referred to certain enduring goals in a quality education while the development of a school's culture for the exercise of higher order leadership, attention must also be given to technical, human, and educational facets of leadership.... . the principals and other leader should be adept at empowering others.... . school leader should also be adept in the way they manage symbols... Dramatic conciseness is important in the exercise of cultural leadership (Caldwell B.J. \& Spink, J.M., 85).

Pada kutipan di atas lebih jelas dapat dipahami bahwa kepala madrasah dituntut untuk membangun budaya madrasah, dengan menekankan pada elemen-elemen dasar dari keunggulan madrasah. Dia diharapkan dapat membuat perubahan sebagai sikap respek terhadap kehidupan sosial masyarakat secara keseluruhan, semua anggota madrasah dibina untuk pencapaian tujuan bagi kualitas pendidikan. Dalam konteks di atas, bahwa kepemimpinan kepala madrasah dibutuhkan secara teknis, manusiawi dan kependidikan.

Berdasarkan beberapa penjelasan di atas, dapat dipahami, bahwa kepemimpinan kepala madrasah dapat meningkatkan budaya madrasah, merujuk pada bagaimana ia dapat mengembangkan budaya unggul (the culture of excellence) di madrasah. Kepala madrasah hendaknya menekankan akan pentingnya membangun budaya yang memberikan konstribusi terhadap peningkatan kualitas proses pendidikan di madrasah. Langkah-langkah yang perlu dilakukan seperti: memahami budaya madrasah, komunitas madrasah memahami nilai-nilai keunggulan, elemen-elemen budaya kualitas, membangun perubahan budaya sesuai tuntutan masyarakat. Dalam kondisi ini maka kepemimpinan yang dibutuhkan dalam membangun budaya organisasi adalah kepemimpinan yang mencakup kemampuan teknis, manusiawi dan kependidikan.

Dari beberapa pemahaman dasar tentang peran kepemimpinan kepala madrasah dalam pengembangan budaya mutu madrasah, dapat ditemukan beberapa unsur utama, yang melandasi kerangka berpikir dalam tulisan ini yaitu: kepala madrasah mengartikulasikan visi dan misi madrasah, nilai-nilai dan keyakinan dalam organisasi madrasah, menciptakan simbol-simbol yang dapat memperkuat keunikan madrasah, membangun sistem reward yang sesuai dengan norma dan nilai yang ada di madrasah, membangun hubungan sosial dan emosional antara siswa, guru, dan masyarakat atas dasar komitmen dan misi organisasi madrasah, dan mendesain struktur organisasi madrasah.

\section{a. Kepala Madrasah Mengartikulasikan Visi dan Misi Madrasah}

Dalam proses kepemimpinan, seorang kepala madrasah dituntut untuk merumuskan dan menciptakan visi dan misi madrasah sebagai 
kesatuan ide dan perekat bagi anggota organisasi madrasah. Visi dan misi menjadi milik madrasah yang berusaha untuk diwujudkan dalam mengembangkan peran dan tugas masing-masing individu dan kelompok di madrasah.

Terbentuknya visi dan misi madrasah yang kuat merupakan hasil dari sudut pandang dan harapan kepala madrasah terhadap madrasah yang sedang dipimpinnya.

Visi dan misi merupakan maksud dan kegiatan utama yang membuat organisasi memiliki jati diri yang khas sekaligus membedakan dengan organisasi lain. Visi dan misi yang dimiliki madrasah harus merupakan karakter dari organisasi yang diterjemahkan dalam aktivitas yang lebih operasional sehingga dalam melahirkan visi dan misi yang baik, setidaknya mencakup tugas dan fungsi, filosofis dasar organisasi apa yang ditawarkan, untuk siapa dan untuk apa madrasah tersebut.

Menurut Yukl, memahami visi dan misi merupakan hal saling menyatu di mana visi merupakan sumber harga diri dan tujuan bersama bagi para anggota organisasi. Visi sebagai sebuah gambar yang menarik dan intuitif mengenai bangsa sekarang untuk masa depan. Visi dapat diartikulasikan dalam bentuk pernyataan misi yang mengandung nilainilai dan tema utama organisasi (Yukl, G., 1999: 77).

Sumarso membedakan visi dan misi dalam kerangka tujuan masing-masing, yaitu visi terkait dengan apa yang didambakan di masa depan dan masa datang tentang dambaan kita akan menjadi apa di masa depan (what do we want to have dan what do we want to be).

Visi yang baik mempunyai ciri-ciri sebagai berikut:

1) memperjelas arah tujuan

2) mudah dimengerti dan diartikulasi dengan baik

3) mencerminkan cita-cita tinggi dan menetapkan standar unggul

4) menumbuhkan inspirasi, semangat, kegairahan, komitmen

5) menciptakan makna bagi organisasi

6) merefleksikan keistimewan organisasi

7) mencerminkan nilai-nilai yang dijunjung tinggi oleh organisasi

8) kontekstual terkait orang dan lingkungan sejarah perkembangan organisasi (Eko Susilo, 2003: 44).

Murgatroyd S. dan Morgan Collin (dikutip oleh Eko Susilo) menegaskan 3 fungsi misi:

1) memberi inspirasi bagi anggota organisasi 
2) dasar pembuatan kepemimpinan organisasi

3) menggerakkan energi anggota organisasi agar terfokus pada perbaikan mutu (Eko Susilo, 2003: 44).

Osborne dan Gaebler menyatakan misi akan menggerakkan organisasi lebih baik, adapun keunggulan misi:

1) organisasi digerakkan oleh misi lebih efisien

2) organisasi digerakkan oleh misi lebih efektif

3) organisasi digerakkan oleh misi lebih fleksibel

4) organisasi digerakkan oleh misi lebih semangat (Osborne dan Gaebler, 1992: 98).

Visi dan misi yang kuat dapat menjadi milik organisasi melalui proses yang terkelola dan terencana secara baik oleh seorang pemimpin organisasi madrasah Menurut Saskhin dan Molly menjelaskan 4 langkah dalam membangun visi yang kuat:

1) mengekplorasi visi

2) menjelaskan sebuah visi

3) melaksanakan sebuah visi

4) memperluas jangkauan sebuah visi (Sashkin M. dan Molly GS., 2003: 25).

Melalui proses di atas maka visi dapat menjadi milik organisasi sehingga anggota dapat memahami, menghayati dan melaksanakan sesuai peran dan tanggungjawab masing-masing individu dan kelompok. Sebuah visi yang kuat dan baik tentu tidak dapat menjadi milik organisasi tanpa melalui proses menciptakan secara demokratis. Peran dan tanggungjawab pemimpin untuk menciptakan visi yang kuat dan baik bagi organisasi, tanpa peran kepemimpinan yang kuat akan mengalami kesulitan untuk melahirkan visi yang kuat bagi organisasi.

Oleh karena itu dalam berbagai rekrutmen kepemimpinan, visi dan misi organisasi seorang pemimpin merupakan bagian penting dari apa yang dilakukan untuk memimpin sebuah organisasi. Visi dan misi merupakan gambaran umum atau cetak biru dari realitas serta masa depan organisasi yang dipimpin, sehingga visi dan misi bersifat powerfull dalam menggerakkan organisasi. Jadi visi merupakan kepemilikan (ownership) dan komitmen dasar dalam diri organisasi yang didambakan anggota dan masyarakat luas.

b. Mengartikulasikan Nilai-nilai dan Keyakinan dalam Organisasi Madrasah 
Ide-ide mendasar yang sesuai dengan yang diinginkan, yang benar dan yang baik oleh sebagian besar anggota organisasi. Madrasah sebagai organisasi mempunyai nilai-nilai yang diyakini oleh anggota organisasi yang termanifestasi pada cara berpikir, bertindak dan menyikapi hal-hal yang terkait dengan madrasah.

Nilai dan keyakinan dalam kepemimpinan merupakan landasan filosofis semangat organisasi (spirit of organization), sehingga roda organisasi dapat bergerak sesuai dengan visi dan misi yang diharapkan. Nilai dan keyakinan seorang pemimpin tentang organisasi yang dipimpinnya merupakan dimensi tindakan dan dan nilai-nilai universal yang diemban madrasah, yang merupakan refleksi dari nilai dan keyakinan masyarakat madrasah.

Nilai dan keyakinan yang dimiliki seorang pemimpin, biasanya termanifestasikan dalam diri organisasi. Di mana pemimpin berupaya agar nilai dan keyakinannya dapat menjadi harapan dan milik anggota organisasi. Peran dan tanggungjawab kepala madrasah untuk menstransformasikan nilai dan keyakinan agar terwujud sebagai bentuk perilaku organsiasi. Kepala madrasah mengarahkan nilai dan keyakinan untuk membangun budaya madrasah yang unggul (culture of exellence school).

Menurut Spink dan Caldwell nilai dan keyakinan dalam organisasi madrasah yang perlu menjadi perhatian untuk mencapai keunggulan madrasah, yaitu kualitas, keefektifan, persamaan, efisiensi dan pemberdayaan (Caldwell B.J. \& Spink, J.M., 93). Eko Susilo menemukan bahwa keunggulan madrasah tercapai karena didukung dengan nilai-nilai dasar yang diyakini kepala madrasah dan anggota organisasi. Sejauh mana nilai dan keyakinan dapat memberi konstribusi besar dalam menggerakkan roda organisasi sangat tergantung pada peran dan tanggungjawab kepala madrasah. Ia dituntut untuk mengkomunikasikan nilai dan keyakinan organisasi agar memberikan dampak positif terhadap perilaku anggotanya. Siswa, guru, staf, orangtua dan masyarakat harus memahami, menghayati dan mengartikulasikan nilai dan keyakinan madrasah, menggerakkan sumber daya madrasah untuk mencapai tujuan kepala madrasah, diharapkan dapat membangun nilai dan keyakinan madrasah yang kokoh sebagai landasan untuk membangun madrasah yang baik. Nilai dan keyakinan dapat menjadi landasan moral perilaku anggota organisasi madrasah. Kepala madrasah membangun nilai dan keyakinan anggota didasarkan pada visi dan misi madrasah tersebut.

Madrasah yang memiliki budaya mutu dapat dilihat dari kemampuan madrasah ini untuk menciptakan seperangkat norma sebagai acuan anggota organisasi dalam berperilaku di madrasah. Di sinilah kepala madrasah dituntut untuk membangun norma madrasah agar tercipta iklim madrasah yang bermutu. 


\section{c. Menciptakan Simbol yang Dapat Memperkuat Keunikan Madrasah}

Simbol adalah tindakan atau obyek-obyek material yang diterima secara sosial sebagai gambaran nyata tentang sesuatu. Demikian juga Schein menekankan bahwa pemimpin menetapkan simbol untuk menciptakan motivasi dan prestasi anggotanya, sehingga simbol suatu organisasi merupakan suatu bentuk pemaknaan lebih kongkrit dari apa yang diinginkan dan diharapkan. Simbol dapat berupa tindakan nyata yang dapat membawa implikasi terhadap organisasi. Untuk itulah aktivitas-aktivitas madrasah dapat dijadikan sebagai simbol yang jelas tentang apa yang menjadi harapan semua komponen madrasah. Dalam konteks ini, kepala madrasah melakukan program-program madrasah sebagai pemaknaan nilai pada simbol madrasah.

Di samping itu, simbol merupakan sarana dan prasarana yang dibutuhkan untuk mencapai tujuan organisasi. Sarana dan prasarana madrasah sebagai simbol dari upaya-upaya yang sedang dilakukan madrasah dalam rangka meningkatkan mutu, termasuk juga lingkungan madrasah yang kondusif akan memberikan dampak pada terciptanya mutu yang unggul.

Kepemimpinan kepala madrasah pada budaya madrasah dapat dilihat dari kuatnya sistem simbol yang diciptakan dalam organisasi. Hal ini dimaksudkan untuk meningkatkan apresiasi siswa, guru, karyawan, orangtua dan masyarakat terhadap keunggulan madrasah. Melalui simbol dapat diilustrasikan tentang sesuatu yang dihargai, sesuatu yang bermakna, sesuatu yang diinginkan dalam mencapai tujuan organisasi.

Kepala madrasah sebagai pucuk pimpinan organisasi hendaknya mensosialisasikan simbol-simbol madrasah. Simbol-simbol organisasi madrasah hendaknya mencerminkan harapan semua pihak terhadap keistimewaan madrasah yang akan dicapai dalam jangka pendek atau jangka panjang. Untuk lebih memahami pencitraan madrasah maka diperlukan simbol-simbol yang mampu merepresentasikan keistemewaan madrasah. Tentunya simbol akan memberikan makna bagi semua elemen madrasah manakala ia dijadikan sumber inspirasi untuk meningkatkan kemajuan madrasah, hingga siswa, guru, karyawan, orangtua dan masyarakat menjadi simbol madrasah sebagai sebuah citra dan cita madrasah.

\section{d. Membangun Sistem Reward yang Sesuai dengan Norma dan Nilai yang Ada di Madrasah}

Jenis penghargaan dikelompokkan menjadi dua yaitu bersifat instrinsik dan ekstrinsik. Penghargaan instrinsik, yaitu penghargaan yang diberikan karena melaksanakan tugas-tugasnya. Penghargaan ekstrinsik ada yang bersifat kompensasi langsung atau tidak langsung. Penghargaan 
yang dilakukan kepala madrasah hendaknya dapat menjadi motivasi bagi para guru dan karyawan untuk meningkatkan unjuk kerja. Pentingnya penghargaan bagi seorang pemimpin karena ia dapat menjadi sumber kekuasaan yang dapat digunakan untuk mempengaruhi anggota organisasi. Peran dan tugas kepala madrasah untuk menciptakan sistem reward yang proporsional dan profesional akan sangat mendukung lahirnya budaya organisasi yang sehat. Sistem penghargaan yang baik akan meningkatkan moral kerja guru dan karyawan dalam mencapai tujuan organisasi yang telah ditetapkan. Di sini pentingnya peran kepala madrasah untuk mendesain sistem penghargaan secara profesional dan dapat diterima bawahannya, sebagai sistem organisasi yang baik.

e. Membangun Hubungan Sosial dan Emosional antara Siswa, Guru, dan Masyarakat atas Dasar Komitmen dan Misi Organisasi Madrasah

Hubungan emosional dan sosial pemimpin dengan bawahan harus mampu menciptakan budaya organisasi yang sehat. Kepemimpinan membutuhkan terciptanya hubungan yang konstruktif antara pemimpin dengan yang dipimpin. Kemampuan kepala madrasah dalam membangun hubungan sosial dan emosional yang baik di madrasah sangat dibutuhkan aspek interpersonal dan intrapersonal kepala madrasah.

Aspek interpersonal terkait dengan kemampuan kepala madrasah untuk menjalin hubungan dengan orang lain. Sedangkan aspek intrapersonal terkait dengan kepribadian kepala madrasah. Baik interpersonal ataupun intrapersonal akan mempengaruhi sejauh mana kepala madrasah dapat menciptakan hubungan sosial dan emosional dengan guru, karyawan dan siswa.

Kepala madrasah dalam membina hubungan sosial dan emosional hendaknya memperhatikan perilaku-perilaku bawahan agar diarahkan untuk terciptanya lingkungan sosial madrasah yang harmonis. Dalam rangka hal ini, ia dapat melakukan kritik yang membangun, meningkatkan integritas pribadi dan mengembangkan pola hubungan yang manusiawi antar anggota organisasi.

\section{f. Menciptakan Desain dan Struktur Organisasi Madrasah}

Desain organisasi merupakan hubungan organisatoris antara komponen baik yang bersifat vertikal maupun horisontal. . Menurut Robbin, dkk, desain terdiri dari dua model, yaitu mechanistic structure dan organic structure (Stephen P. Robbins: 547). Yang pertama mempunyai kompleks yang tinggi, formalitas tinggi dan sentralisasi. Yang kedua, kompleksitas rendah, formalitas rendah dan desentralisasi. 
Sebuah desain dan struktur selalu berangkat dari kebutuhan organisasi untuk mewujudkan tuuan jangka panjang dan jangka pendek. Visi dan misi sering mewarnai bagaimana struktur dan desain akan diarahkan.

Desain organisasi madrasah menjadi bagian penting untuk meningkatkan kefektifan dan efisiensi organisasi. Organisasi madrasah berupaya mengembangkan langkah organisatoris untuk menciptakan kondisi madrasah yang profesional. Keterlibatan unsur pimpinan dalam menciptakan desain organisasi, akan memberi pengaruh pada peningkatan kualitas pengelolaan madrasah.

Desain organisasi madrasah akan memberikan pengaruh pada budaya organisasi yang berkembang di madrasah. Kepemimpinan kepala madrasah akan tergambar dari desain dan struktur organsisasi yang dilakukan dalam menerapkan sistem kontrol dan pengelolaan yang profesional. Itulah desain dan struktur madrasah akan sangat dipengaruhi oleh kepemimpinan kepala madrasah. Dan sisi individual kepala madrasah, khususnya budaya organisasi akan mencerminkan tata hubungan antar lembaga-lembaga madrasah.

\section{Penutup}

Hubungan kepemimpinan dan budaya organisasi merupakan dimensi sosial organisasi yang belakangan menjadi kajian yang menarik. Kajian kepemimpinan yang menekankan pendekatan ciri, perilaku, kekuasaan dan pengaruh, dan situasional yang masih bersifat satu arah. Perspektif organisasi sebagai sistem sosial telah memberikan dimensi budaya sebagai bagian penting yang mempengaruhi keefektifan kepemimpinan. Dari sini lahir rasional bahwa kepemimpinan yang efektif dalam suatu organisasi sangat dipengaruhi oleh nilai, keyakinan dan perilaku pemimpin yang termanifestasikan dalam kehidupan organisasi dan mencakup semua unsur dalam cakupan budaya organisasi dalam arti yang luas.

Perkembangan organisasi madrasah menjadi lembaga pendidikan semakin memerlukan pengelolaan secara professional. Dimensi kepemimpinan kepala madrasah sebagai bagian utama dari perhatian manajemen pendidikan untuk meningkatkan keefektifan dan efesiensi madrasah. Posisi kepala madrasah sebagai penanggungjawab kesuksesan atau kegagalan madrasah dalam melakukan pembelajaran akan sangat tergantung pada upaya mengoptimalkan peran dan tugas kepemimpinan secara efektif. Sisi penting dari organisasi madrasah adalah budaya organisasi yang dikembangkan kepala madrasah untuk meningkatkan kualitas pendidikan.

Keterkaitan perilaku pemimpin dengan budaya oraganisasi dapat dilihat dari bagaimana pemimpin membentuk atau mempertahankan 
budaya madrasah yang kuat (Strength of cultural school). Hal ini dapat dilihat dalam penjelasan Yukl, sebagai refleksi dari penelitian Trice dan Beyer tentang kepemimpinan pada budaya organisasi sebagai berikut:

Budaya dipengaruhi oleh berbagai perilaku seorang pemimpin, termasuk contoh contoh yang diterapkan oleh seorang pemimpin, apa yang diperhatikan pemimpin, cara pemimpin tersebut bereaksi terhadap kritik, cara pemimpin tersebut mengalokasikan imbalan-imbalan, dan cara pemimpin tersebut membuat pilihan, promosi, dan keputusan-keputusan memberhentikan orang. Mekanisme-mekanisme tambahan untuk membentuk budaya termasuk rancangan struktur organisasi, sistem manajemen, fasilitas, pernyataan formal tentang ideologi, dan kisah-kisah formal, dongeng-dongeng serta legenda-legenda. Jauh lebih mudah untuk menanamkan budaya dalam organisasi yang baru daripada merubah budaya organisasi yang sudah dewasa. Namun demikian, kepemimpinan kultural juga penting untuk memperkuat budaya dalam sebuah organisasi yang ada saat ini makmur atau berhasil (Yukl, G., 1999: 318).

Berdasarkan kutipan di atas dapat dipahami bahwa budaya organisasi dipengaruh oleh sejauh mana kepemimpinan dapat mengarahkan aktivitas organisasi, baik yang tampak (Tangable) atau tidak tampak (Intangable) untuk membangun budaya organisasi yang kuat. Di sini seseorang pemimpin dituntut untuk mengelola unsur-unsur budaya organisasi sebagai sebuah manifestasi dalam bentuk keyakinan, nilai dan semua perilaku anggota. Sebuah hubungan budaya dan kepemimpinan dapat digambarkan sebagai berikut:

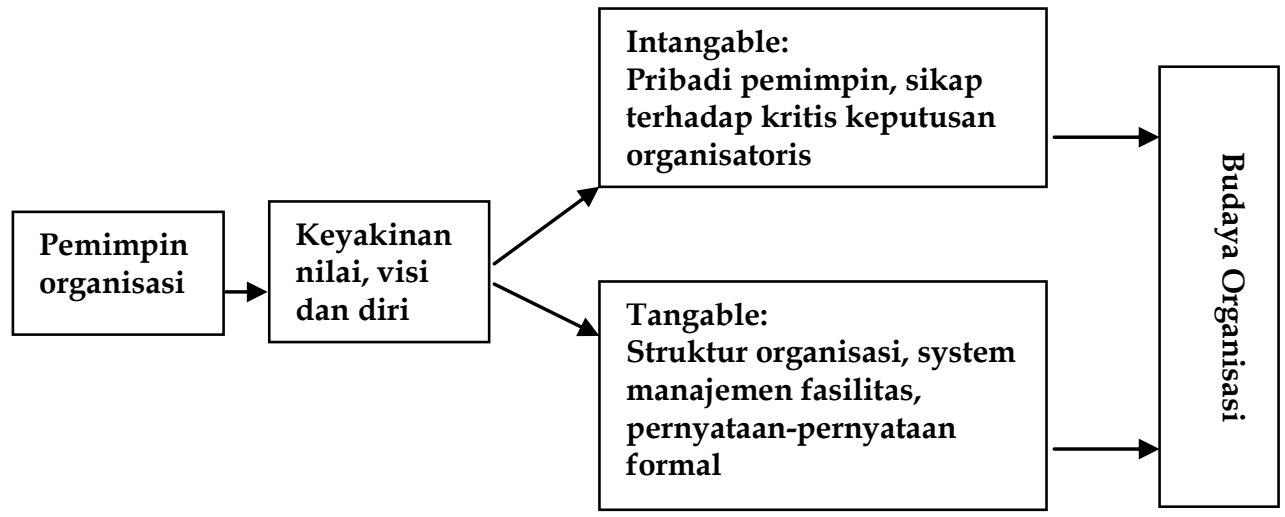

Gambar 4. Rangkaian Pemimpin dalam Membentuk Budaya Organisasi

(Sumber: Yukl, G., 1999: 318)

Jadi jelas sekali bahwa peran pemimpin dalam membangun budaya organisasi yang sangat strategis. Karena pemimpin merupakan orang yang akan menerjemahkan visi, misi serta tujuan organisasi yang harus dicapai dalam jangka waktu yang telah ditentukan. Kepemimpinan berfungsi 
untuk mengarahkan semua sumber daya organisasi untuk mencapai tujuan tersebut.

Kotter dan Heskett menggambarkan proses terbentuknya budaya organisasi berawal dari manajemen puncak yang mentransformasi visi, nilai, dan keyakinan organisasi kepada stafnya sehingga menjadi sebuah perilaku, yang kemudian menjadi berkesinambungan dari tahun ke tahun serta terbentuklah budaya organisasi yang kuat. Lebih jelas tentang terbentuknya proses budaya organisasi dapat dilihat dari gambar berikut ini:

\section{Manajemen Puncak}

Seorang atau para pucuk pimpinan organisasi yang masih baru mengembangkan dan berusaha mengimplementasikan suatu visi/filosofi atau strategi bisnis

\section{Perilaku Organisasi}

Karya-karya implementasi. Orang berperilaku melalui cara yang dipandu oleh filosofi dan strategi

\section{Hasil}

Dipandang dari berbagai segi, orang itu berhasil dan keberhasilannya itu terus berkesinambungan selama bertahun-tahun.

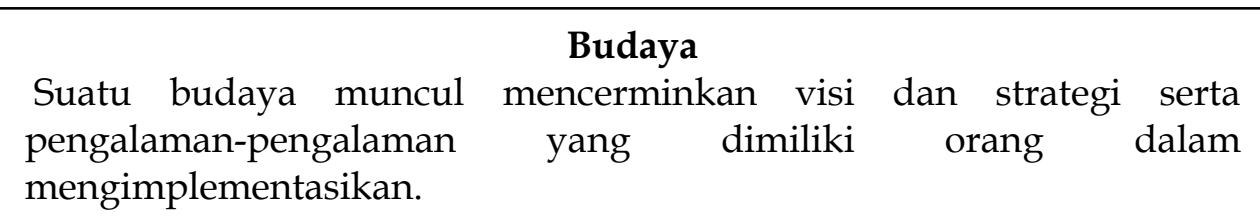

\section{Gambar 5. Proses Terbentuknya Budaya Organisasi}

$$
\text { (Kotter \& Heskett J.L., 1997: 9) }
$$

Peran kepemimpinan dalam menciptakan budaya organisasi yang kuat merupakan rangkaian proses dari keseluruhan sistem organisasi. Dari kutipan di atas dapat dipahami bahwa proses terbentuknya budaya organisasi berawal dari pimpinan puncak yang berupaya mengimplementasikan filosofi, visi dan strategi organisasi. Filosofi, visi dan strategi kemudian termanifestasi pada perilaku organisasi. Budaya organisasi mencerminkan visi dan strategi serta bagaimana mengimplementasikannya dalam sistem organisasi yang dinamis. Perilaku organisasi akan membentuk suatu budaya yang berkesinambungan dari tahun ke tahun yang memberikan hasil nyata bagi pencapaian tujuan organisasi. 
Kemampuan seorang pemimpin dalam mengembangkan budaya madrasah yang kuat tidak lepas dari keyakinan, nilai dan perilaku yang dikembangkan kepala madrasah dalam organisasi madrasah. Dapat dipahami bahwa hubungan kepemimpinan kepala madrasah dan budaya organisasi merupakan hubungan transformatif dan konstruktif, di mana kepala madrasah mempunyai peran dalam mempengaruhi arah dan orientasi perubahan dan perkembangan budaya madrasah.

\section{E. Daftar Pustaka}

Al-Bukhari, tt. Shahih Bukhari. Hadits no. 844. Hadits Syarif. tp.

B.J., Caldwell, \& JM., Spink, Leading the Self Managing School, London: The Falmer Press,1992.

Craig R. Hickman and Michail A. Silva, 1984. Creating Excellence, Managing Corporate Culture Strategy, and Change in the New Age. New York. A Plume Book.

Daft, Richard, Organization Theory and Design $8^{\text {th }}$ Edition, Ohio: Thompson, 2004

Departemen Agama RI. 2005. Al Hikmah, Al Qur'an dan Terjemahnya. Bandung. Diponegoro.

Ekosusilo, Madyo, Sekolah Unggul Berbasis Nilai, Surakarta: Univet Bantara Press, 2003

Hanson E.M.. 1991. Educational Administration and Organizational Behaviour. Newton.

Kotter \& Heskett J.L. 1997. Dampak Budaya Perusahaan terhadap Kinerja. Terjemahan: Benyamin Molan. Jakarta. Prenhallindo.

Owens R.G. 1991. Organizations Behaviour in Education. Englewood Cliffs New Jersey. Prentice Hall.

Poerwanto. 2008. Budaya Perusahaan. Yogyakarta. Pustaka Pelajar.

Schein, H.E. 1992. Organizational Culture and Leadership. San Francisco. Jersey-Bass Publishers.

Sergiovanni, Thomas J.,et.al., Educational Government of Administration, New Jersey: Prentice Hall Inc., 1991

Stone, W. F. T., \& Wilson, B.L. 1985. Using Bureaucratic and Cultural Linkages to Improve Instructional: The Principle Contribution. EAQ. Vol. 21. No.2. Spring.

Yukl, G. 1999. Leadership in Organization, Kepemimpinan dalam Organisasi (Edisi Bahasa Indonesia). Alih Bahasa: Udaya. Jakarta. Prentice Hall. 
Mulyadi - Peran Kepemimpinan Kepala Madrasah

Madrasah, Vol. II No. 1 Juli - Desember 2009 